\title{
Dancing with the Stars: The Practical Value of Theory in Managing Star Employees
}

\author{
Shad Morris \\ Brigham Young University Law School, morris@byu.edu
}

Sharon A. Alvarez

University of Pittsburgh, salvarez@katz.pitt.edu

Jay B. Barney

University of Utah, jay.barney@eccles.utah.edu

Follow this and additional works at: https://scholarsarchive.byu.edu/facpub

Part of the Arts Management Commons

\section{Original Publication Citation}

Morris, S., Alvarez, S., \& Barney, J. Dancing with the Stars. Forthcoming. Academy of Management Perspectives

\section{BYU ScholarsArchive Citation}

Morris, Shad; Alvarez, Sharon A.; and Barney, Jay B., "Dancing with the Stars: The Practical Value of Theory in Managing Star Employees" (2020). Faculty Publications. 3675.

https://scholarsarchive.byu.edu/facpub/3675 


\title{
DANCING WITH THE STARS: THE PRACTICAL VALUE OF THEORY IN MANAGING STAR EMPLOYEES
}

\author{
Shad S. Morris \\ Brigham Young University \\ morris@byu.edu \\ Sharon A. Alvarez \\ University of Pittsburgh \\ salvarez@katz.pitt.edu \\ Jay B. Barney \\ University of Utah \\ jay.barney@eccles.utah.edu
}

\begin{abstract}
Star employees create disproportionate value for organizations. However, managing stars is decidedly difficult. Scholars have not yet appropriately addressed this practical problem. Much of the problem is interpreting our theoretical models that convey human capital from a static perspective. By combining incomplete contract theory with human capital research and theories of strategy, we show how existing theory can provide a framework for solving problems related to managing stars while also offering a platform for further research within the strategic human capital field. To do this, we recap extant theory and examine how stars create value for an organization by co-developing firm-specific while simultaneously developing general human capital. Second, we provide a practical dynamic value appropriation framework illustrating how the employer and the employee determine who captures the value stars create as they go through the employment life cycle.
\end{abstract}


Dancing with the Stars is a reality TV series that pairs a celebrity with a professional dancer in a dance partnership to compete with other dance partnerships. The partnership wins by performing better than the other partnerships in the competition. Winning the competition depends on the celebrity developing general dance skills, but more importantly it depends on how the star develops complementary skills with his or her partner. Developing complementary dance skills and the ability to adapt to one another's moves is something that occurs over time and requires give and take by both partners. Managing star employees in an organization is a surprisingly similar dance. Organizations approach their relationships with stars in a way that resembles a dance of give and take.

But managing this give and take with star employees is decidedly difficult. Organizations are not only going up against a global field of competitors who can hire digitally from across the world. They are also competing with the gig economy where star employees can demand top rates and complete autonomy for short-term engagements as independent contractors (Daniel, Di Domenico \& Nunan, 2018). In fact, star employees are more prone to leave an organization because they are highly visible and create disproportionate value through their high levels of productivity (Brymer \& Sirmon, 2018; Hannan, Burton, \& Baron, 1996; Groysberg, Lee, and Nanda 2008; Trevor and Nyberg 2008). Moreover, scholars have shown that stars are much more valuable to the organization than their less productive peers (Aguinis, O'Boyle, Gonzalez-Mule \& Joo, 2016; O’Boyle \& Kroska, 2017). As a result, such employees can demand higher rates in terms of economic value during employment negotiations (Capelli, 2008; Gardner, 2005). So how much should organizations be willing to pay for star employees and what should they do to adapt to the shifting environment in which they are managed? 
This practical problem has created tremendous angst for organizations, with limited insight provided by scholars. We struggle to know how much discretion to give to stars and how much to pay them. There are times we want them to lead the dance by making decisions for the organization and there are times we want them to adapt and follow the shifts within the organization. We strive to pay them competitively so they will not go find another dance partner, but we also need to be able to capture some value from the work they do (Boxall, 2013; Collings, 2014). After all, both dance partners need to get some benefit from the dance.

Yet, the research examining stars has not kept up with this dance. Traditional research examines value capture from a static fixed point in time, ignoring the actual dancing (i.e., recontracting) that goes on between organizations and employees (cf., Coff 2010; Sparrow \& Makram, 2015). To better understand this dance between star employees and organizations, we need to understand the process of who captures value and when (Lepak, Smith, and Taylor, 2007). Doing so requires a dance of interchanging value between an organization and its employees as they reach stardom. Scholars have only begun to acknowledge that this dance, which consists of the development of firm-specific and general human capital, creates value for the organization but also likely increases an employee's marketability. During this process, both the organization and the employee decrease the information asymmetries between them and often the external market. The challenge organization's face is how to balance and negotiate value capture as the skills their employees possess become more valuable to the organization and more visible to external competitors.

The purpose of this paper is to provide a forum to help address this challenge. First, we recap extant theory and examine how stars create value for an organization by co-developing firm-specific human capital that simultaneously develops general human capital. Second, we 
provide a more practical dynamic value appropriation framework illustrating how the employer and the employee determine who captures the value stars create as they develop (cf., Carmichael, 1983; Jovanovic, 1979). We draw upon a seldom used theory by organizational scholarsincomplete contract theory (ICT) — as a mechanism to extend our thinking around human capital and value creation and capture as it pertains to stars. To date, academics and practitioners alike have not adequately addressed the importance of value capture, stars, and re-contracting (Coff \& Kryscynski, 2010; Sparrow \& Makram, 2015). Although scholars (e.g., Coff, 2010) have noted that bargaining power may shift between parties during employment specific occurrences-and the implications of these shifts-have not been identified in a dynamic process. This paper isolates such conditions and discusses the implications for future research.

\section{Human Capital and Value Creation}

The most widely accepted definition identifies stars as highly productive individuals with high market visibility (Groyberg, Lee \& Nanda, 2008). However, scholars have pointed out that perhaps this definition is too static and void of context. For example, Oldroyd and Morris (2012) ran a simulation on how employees' networks exponentially grow as they become stars. They found that employees with proportionally higher levels of social capital possessed cumulative advantage where the more social capital they possessed, the more they were able to obtain going forward. Aguinis, O’Boyle, Gonzalez-Mule and Joo (2016) later proved this notion of cumulative advantage among stars using a sample of 625,000 individuals. Call, Nyberg and Tatcher (2015) further enhanced the definition of a star as someone with relevant social capital. They discussed that social capital begets social capital and that through deliberate practice employees develop the ability and motivation to find the opportunities that enable them to 
become stars. Likewise, Kehoe and Tzabbar (2014) find that stars emerge not just from performing well, but also from collaborating well.

To further explain how stars create value for organizations, Kehoe, Lepak and Bentley (2016) pointed out that stars contribute to organizations either through task performance or status. Task performance refers to an individual's effectiveness in a relevant context (O'Boyle \& Aguinis, 2012), while status is viewed as the amount of respect, influence and admiration and individual enjoys in the eyes of others - inside and outside the organization. From a value creation perspective, being able to perform well on a task and achieving high status among your peers and competitors is the result of human capital investments made by the employee (Kehoe et al., 2016). In fact, a star's bargaining power with the organization depends on the types of human capital investments she has made and how they create economic value for the organization (Ganco, Franco \& Agarwal, 2012; Ployhart \& Moliteron, 2011).

Two types of human capital are described in the literature: General and specific (Becker 1964). As its name implies, general human capital can create economic value in a wide variety of settings. Some very general forms of human capital include the ability to read, to write, and to do simple arithmetic. Some skills, though not as widely applicable as these, are still considered to be general in nature; e.g., leadership ability, the ability to communicate with and motivate others, the ability to work with others to solve problems (Lazear 2000).

People invest in general human capital in anticipation of some reward (often earnings) (Wright and McMahan 1992). This provides them with bargaining power with employers, as employers are usually willing to pay more for employees with generally applicable skills that can be used to increase productivity, create knowledge, or develop additional human capital. Because general human capital is not always readily apparent, employees will work to obtain degrees, 
certificates, and other such credentials to signal their worth to an employer (Spence, 1973).

These general skills allow employees to capture more of the value they create but are often seen as less valuable to the firm than specific human capital (Barney, 1991).

However, it has typically been viewed that from an employee's perspective, specific human capital is valuable in a narrower range of settings, such as a particular economic exchange, a particular firm, and so forth. While practitioners rarely think of firm-specific human capital in the way that scholars do (Kryscynski \& Ulrich, 2015), it is of central importance in helping employers and employees understand the employment negotiation process. Examples of firm-specific human capital include knowledge about how to accomplish complex tasks in a particular firm, trust among a team of employees within a firm, a sense of commitment to a firm's success, and so forth (Barney and Hansen, 1994; Conner and Prahalad, 1996). According to resource-based arguments, firm-specific human capital can be a valuable source of firm value because it is not subject to the same degree of imitability as general human capital (Barney, 1991; Wright and McMahan, 1992).

For example, Huselid (1995) pointed out that firm-specific human capital investments qualitatively differentiate a firm's employees from those of its competitors. Differentiation in human capital creates opportunities for employees to solve real business problems such as shortening product development cycle times or providing customer service in a way that creates “idiosyncratic contingencies" (Becker and Gerhardt, 1996; Huselid and Becker, 1992). For instance, Batt (2002) found that firm-specific investments help employees to effectively interact with customers. These investments are manifest in the employees' ability to persuade customers to buy a firm's products and services by understanding specific product features, service agreements, pricing, packaging, promotions for particular customer segments, and legal 
regulations. Benefits to the firm are directly attributed to employees' ability to generate more sales but what has been suggested is that these firm specific investments by employees have indirectly rendered the employee less mobile (Parsons, 1972).

Becker's (1964) original insight about general and firm-specific human capital is that employees usually are unable to capture the value of their investments in firm-specific human capital. This is because this type of capital, by definition, is of lesser value to other firms (i.e., firms other than the firm in which the firm-specific human capital was created). It follows that these other firms will not be willing to compensate employees for specific investments made at a previous employer. Unless external competitors are willing to pay for the investments made by employees in one firm, the firm where employees have made specific investments will not be compelled to compensate employees for these specific investments (Becker, 1964).

Williamson $(1975,1985)$ extends Becker's (1964) argument into transaction-cost economics (TCE). According to Williamson, employees may not be compensated for making firm-specific investments and they also put themselves in a position of being opportunistically exploited by the firms in which they have invested. For example, a firm might ask its employees to make firm-specific investments in return for some payment at a future date - a bonus when the profits generated by these investments are realized, a steady income at retirement, and so forth. However, once these specific investments are made, a firm may choose to behave opportunistically and renege on its promises.

For example, beginning in the 1980s companies were persuaded by an increased focus on shareholder value to divest non-related businesses and acquire new ones to capture synergies (Cappelli, 2001). This resulted in markets with employees possessing specialized, niche skills. Many employees who made these specific, niche investments were later pushed outside of the 
firm boundaries in contract or other alternative employment arrangements, freeing the firms from their obligation to provide benefits and other assurances to their employees (Cappelli, 2001). In such settings employees have limited recourse.

\section{The Co-Development of Firm-Specific and General Human Capital}

These received views of human capital and value creation, summarized in Figure 1, have proven fruitful. Yet there are conditions in which these received views do not hold. As a result, scholars have recently offered an alternate theoretical argument, suggesting that general and firm-specific human capital are not separable, especially among high performing employees like scientists, lawyers, professors, investments bankers, physicians, and other knowledge workers (Morris, Alvarez, Barney \& Molloy, 2017). In particular, when workers make firm-specific investments they develop skills that can be valuable to their company (Park, Howard \& Gomulya, 2018) but can also be transferred and valuable to competitors (Greenwood, Hinings and Brown 1990). For example, Morris and colleagues (2017) pointed out that "to the extent that prior firm-specific investments act as a market signal of general human capital, these investments should increase employee mobility (p. 916). Moreover, the skills gained by making specific investments may not all be firm-specific because they are embodied within the individual, who can create new knowledge or use existing knowledge in new ways (Chadwick and Dabu, 2009; Felin and Hesterly 2007). The implication being that while context matters, it is the, "role of the individuals and, more specifically their commitment to the knowledge creating process" that offers sustainable competitive advantage (Nonaka 1994: 15). For example, when a star consultant leaves a firm they often take clients with them, demonstrating the value created was from the consultant's human capital, not firm-specific assets per se (Rocha, Carneiro \& Varum, 
2018). Thus, firm-specific human capital investments may act to generate both firm-specific and general human capital, creating the need to better understand the dynamics between employee firm-specific human capital investments and general human capital investments.

[Insert Figure 1 about here]

As additional evidence that the assumption of general and firm-specific human capital separability is problematic, consider a prototypical example of firm-specific human capital: a person's ability to work with a particular team of employees in a particular firm. These firmspecific investments come as a person works with fellow colleagues to complete a task. Existing theory indicates this investment (i.e., knowledge of these particular people and places) is valuable as long as a person is working with those employees in that context (Lepak and Snell 1999). Theory suggests that the only way this firm-specific investment would be valuable to another firm is if this person's entire team—or at least a large percentage of that team—obtained employment together in another firm (Klein, Crawford, and Alchian 1978).

Yet, this individual made a firm-specific investment (the ability to work with a particular team) and at the same time co-developed general human capital useful in a knowledge or team environment. That is, in the process of figuring out who knows what, where valuable information can be found, and how to build a high performing team to enhance firm competitive advantage (i.e., making firm-specific human capital investments), the individual develops or refines skills useful to many organizations. These general skills might include, for example, experience in working with a team, knowledge of how to help a team develop, understanding of how to use a team to solve business problems, and so forth. These aspects of this individual's human capital are quite general, that is, they are likely to be valuable in any setting that requires team production (Alchian and Demsetz 1972). Given the centrality of teams to knowledge creation, 
strategy formulation and implementation, many firms are likely interested in hiring someone who is good at working in teams, processing information, and solving problems because these tacit skills can create new knowledge (increasing economic value created) and facilitate the employee's quick transition to a new firm (decreasing switching costs). In other words, when a star develops dance moves that are specific to the partner with whom they've been practicing they simultaneously develop general dance moves that can be transferred across partners. Both investments signal to external others that this star would be a great dance partner.

\section{Theoretical Implications for Managing Stars}

Despite traditional arguments that firm-specific human capital investments made by employees have less value outside the firm, the arguments presented in this paper explain why employees who are able to create value for their firms through firm-specific human capital investments are typically sought after on the external labor market. This paper suggests that by making firm-specific investments individuals simultaneously create co-developed human capital, defined as employee firm-specific human capital investments that act as a market signal of an employee's general human capital (Morris, Alvarez, Barney \& Molloy, 2017).

To illustrate, consider Coff's (2012) discussion of human capital investments and hiring in academia. In this setting, general human capital investments would be publications, as these are valued across many institutions. Firm-specific investments would include department and college service responsibilities, such as serving on doctoral committees, preparing for AACSB credentialing reviews, and taking time to interact with recruiters considering hiring the school's students. Prior theory would prescribe that individuals, especially junior faculty, invest solely in general human capital - publications. Yet Coff (2012) asks "Do you really want to hire a person 
who has avoided all service commitments at their prior institution?" (p. 9). Of course professors at a hiring institution would not likely want to hire such a person, as they are likely to continue to shirk important service responsibilities, decreasing their peers' time and resources for their own research and publications. This illustration demonstrates that the prescriptions this revised theory yields for individuals helps to better understand why stars are so highly mobile.

\section{Practical Implications for Managing Stars}

High performing employees (stars) who make generally applicable "specific" investments (i.e., co-developed human capital) send signals to the external market that they have skills applicable to competitors (Morris, Alvarez, Barney \& Molloy, 2017), and these signals may lead to increased mobility (Lee et al. 2008; Trevor, 2001; Trevor et al. 1997; Wright, Tartari \& Huang, 2018). Frank and Cook (1996) argue that runaway salaries of top performing professionals such as bankers, lawyers and consultants result not from the breakdown of competition but rather from the spread of markets in which the value produced by high performing individuals stands in stark contrast to that of other individuals. We argue that it is the combination of general human capital along with skills developed while making firm-specific investments that makes these employees sought after and mobile. These high-performing employees are less likely to stay within an organization unless they are able to capture more of the value they create (Brymer \& Sirmon, 2018). Taylor et al. (1996) also found that higherperforming managers were more likely to leave the firm after they had made considerable investments in terms of tenure than their average-performing peers. In other words, the more time a high performing employee invests in a specific firm the more likely that employee is to leave and potentially work for a competitor. 
Moreover, the "war for talent" literature has shown that certain professional industries typically hire freely from one another and that highly sought employees (stars) possess little loyalty to the company and more to the profession (Gardner 2005; Greenwood et al. 2008). In fact, much of this literature focuses on the mobility and immobility of these individuals (e.g., Groysberg et al. 2008; Marx, Strumsky, and Fleming 2009; Wright, Tartari \& Huang, 2018). From a resource-based approach, some scholars have even discussed how to retain such marketable employees (Brymer \& Sirmon, 2018; Somaya and Williamson 2008; Groysberg and Lee 2010). As originally argued by Maister (1997), managing top performers is an especially pressing issue when firm performance is largely a function of individual employee performance.

At the same time, scholars have shown that as stars develop they are more likely to be given higher workloads than their less productive peers (Morris \& Oldroyd, 2017). These higher workloads often lead to burnout and increase the likelihood that stars will leave the organization, looking for more attractive dance partners (Aguinis \& O’Boyle, 2014; Aguinis, O’Boyle, Gonzalez-Mule \& Joo, 2016). Such issues point to the importance of managing stars carefully. For example, one may find that stars are more inclined to leave an organization if they are micromanaged and told what to do, rather than being sold on a vision of what the organization is trying to accomplish and given autonomy to make decisions for themselves. Since stars possess codeveloped human capital that makes them highly attractive to the outside labor market, it becomes important not just for HR but for all of management to consider how their stars are managed over time.

Indeed, scholars have noted this deficiency in the literature and called for more dynamic models that examine how talent is managed. For example, Boxall (2013) pointed out the need to align individual employee interests with those of the organization. He noted that this alignment is 
not a one-time static fit, but rather required constant adjustments over time, calling for a more dynamic fit model. Moreover, Collings $(2014 ; 2017)$ points out that organizations need to see their employees as stakeholders, where the organization not only tries to find employees who align with their vision but to also align their vision to the constantly changing skills and preferences of their highly valuable employees. Finally, Sparrow and Makram (2015) drew upon dynamic capabilities and global knowledge management research to develop a value-driven process framework for top talent. However, the argument remains that organizations need isolating mechanisms to allow them to constantly capture value from the employee.

Models that suggest isolating mechanisms still fall short (just like the strategy and economics scholars who study human capital) in that they focus on creating frictions and isolating mechanisms that allow the organization to capture some of the value created by employees. In other words, these traditional models of human capital and stars research focuses on trying to make it difficult for the employee to leave by getting them to develop skills that won't be valuable elsewhere. What this papers suggests is that this is not realistic.

What is needed are frameworks that treat employees more like stakeholders or dance partners involved in an incomplete employment contract, where both parties are constantly negotiating value capture and decision rights with one another. Below, we provide a stylized example to illustrate such a dynamic management framework.

\section{Star Employees and Dynamic Value Capture}

The framework in this paper develops the concept of co-developed human capital and its implications by using incomplete contract theory (ICT) (Grossman and Hart 1986; Hart and Moore, 1988). This theory of dynamic value appropriation addresses how the disproportionate 
value created by stars is best captured between the employer and star, as received theory does not address this key practical concern (Groysberg and Lee 2008; Lazear 1986; Milgrom and Oster 1987). To clarify how the theory addresses this deficiency, a stylized illustration and framework are presented using the context of professional service firms-and consulting in particular. This context is particularly fruitful as it illuminates the managerial dilemma necessitating a theory of dynamic value appropriation. In this context, firm performance is highly reliant on their star employees' performance-yet these stars are highly mobile putting at risk the firm's ability to gain and sustain competitive advantages (Coff 1997).

To more effectively understand how organizations dance with stars, existing theory needs to address how to optimize and capture the value stemming from the general human capital stars developed when acquiring firm specific human capital. Such a theory requires understanding value appropriation from a dynamic perspective (Baron, Hannan \& Burton 1999; Lepak et al. 2007) in which the sources of the star's value creation are more discretely examined (i.e., disaggregated into general and firm-specific resources).

Essential to this process is considering star employees' perspectives. For example, stars are likely to expect to receive higher employment outcomes (e.g., compensation, promotions) - and are more sensitive to how value is captured-than their lesser performing peers (Trevor, Hausknecht and Howard 2007). This suggests that stars should be involved in pay and business decisions, which, Coff (1997) argued can be accomplished through human resource management practices and systems. Indeed, human resource systems influence two decisions salient for stars: pay and firm strategy by clarifying what economists call decision rights, or internal organizational agreements about who has the power to make decisions about specific aspects of the firm's operation (e.g., Jensen and Meckling, 1995). Of particular interest are 
decisions about compensation practices and how much of the value the star creates and captures (i.e., value-appropriation decision rights) and decisions about the strategies the firm pursues and how those strategies are implemented (i.e., rights of control) (Delery, Gupta, and Shaw 1997; Gowan and Lepak 2007; Kang, Morris, and Snell 2007; Lepak and Snell 1999; Huselid, 1995; MacDuffie 1995; Rousseau 1995; Tsui, Pearce, Porter Tripoli 1995).

Such discussions of human resource practices and systems have yielded important advances but have not yet fully explored the dynamics involved in retaining employees and how decision rights are negotiated (cf. Coff 2010). In other words, the HR literature yields extensive guidance regarding the initiation-but not the renegotiation-of employment relationships. Similarly, RBT and TCE both indicate that the firm should retain star employees (to provide a social context for the value creation, or to enable managerial fiat and value appropriation, respectively). Yet, human resource, RBT, and TCE scholarship do not indicate how to retain these employees as other firms become aware of their valuable and sought after human capital skills. Simply put, there is little understanding of how value appropriation and control rights can be negotiated between the star and employer to optimize firm and star outcomes (Alvarez and Barney 2005; Coff 2010).

The framework in this paper addresses the renegotiation process between the firm and its star employees. The framework is based on the premises that (1) firms should start the process of renegotiation with employees before they reach elite stardom, and (2) outcomes for firms and stars are optimized when decision rights are determined through an intricate dance of renegotiation that recognizes shifts in the star's bargaining power over the employment lifecycle. To demonstrate this, we first show how ICT (Grossman and Hart 1986; Hart 1988) is well-suited 
for employment relationships and then present a dynamic value appropriation framework (Figure 2), which is explained using a stylized illustration.

[Insert Figure 2 about here]

\section{Incomplete Contract Theory}

Incomplete contract theory was created to explain the governance of exchanges characterized by relationship-specific investments when future outcomes cannot be explicitly contracted for at the time a firm is organized (Grossman and Hart 1986). This theory suggests that these exchanges are plagued by numerous unforeseen contingencies that, by definition, cannot be included in a complete contingency contract (Williamson 1975). Rather than attempting to specify these contracts as complete, ex ante, the theory suggests that parties will specify those contingencies that can be specified, and assign remaining decisions-rights — what the theory calls residual rights of control - to one party. Residual rights of control are often seen as synonymous with ownership (Foss and Foss 2011) and focus on the ability to make decisions about how organizational assets are used (i.e., within circumstances not governed by law or existing contracts) (Grossman and Hart 1986). To maximize the overall economic value the exchange creates, the party that expects to gain the most from this exchange should retain these residual rights (Grossman and Hart 1986). This is because this party has the strongest incentives to maximize the total value created — and the value they might capture (Hart and Moore 1988).

Although not previously applied in human resources, ICT is well-suited for scholarship on employment relationships involving stars, as such employment relationships often occur in settings that are complex and plagued by numerous unforeseen (and thus unverifiable) contingencies (Alvarez and Parker 2009; Grossman and Hart 1986). Indeed, it is often not possible to write complete enforceable contracts to manage certain types of employment 
exchanges ex ante, for many reasons. For example, employment relationships are plagued with informational asymmetries regarding what an employee's actual human capital is (e.g., how smart and conscientious the employee is) and what the employee's intentions are (e.g., to stay with the firm for only a few years as a stepping stone or to pursue promotion within the firm). Moreover, it may not be possible to specify, ex ante, which decision rights the star and organization should retain to maximize the value the star's knowledge creates since the value of an employee's human capital, and its potential generalizability, are not known until the individual becomes an employee and the process of knowledge creation unfolds over the employment lifecycle. After these investments, at some future date, the information asymmetry between the employee and firm regarding the employee's potential and actual contributions should be resolved, which allows for decision rights to be allocated between the star and firm as ICT suggests. Later, if the employee is deemed a star, then it is important for management to move aside and provide the star increased autonomy and allow them to lead and manage themselves.

In the beginning of the employment contract, decision rights regarding value appropriation and rights of firm control belong to the organization. ${ }^{1}$ Yet because employee contracts are incomplete it is necessary to have a mechanism that allows for changes in this initial contract as the informational asymmetries between the firm and star are resolved-and the star's true value creation abilities and track record are revealed. If an employee generates knowledge that creates value for the firm and is also visible and valued by competitors, that employee will likely receive alternative employment offers. Rather than lose the employee to a

\footnotetext{
${ }^{1}$ This is of course assuming that the employees are new hires early in their careers. If you are dealing with seasoned hires, then you will need to adjust your dance to give more control over to the new hire right away.
} 
competitor, the firm may want to renegotiate control rights with the employee rather than have the employee leave. This renegotiation is the "dance" between the firm and star; rather than the firm retaining decision rights (regarding value-appropriation and rights of control), firms wanting to maximize value creation will begin surrendering these decision rights to the employee.

Because the star is able to increase the economic value created (i.e., increase the "size of the pie"), these negotiations are not a zero-sum game. If employment negotiations are successful, the employee will be retained and will be granted a larger share of the economic value they generate. At the same time, by surrendering some decision rights, firms will have the potential to create and capture more value from the employee's human capital. Simply put, by allowing the star to capture more of the value they create and retaining the star, the firm can earn more than losing the star to a competitor.

Inherent to ICT is a Bayesian learning logic (Alvarez and Parker, 2009), in which both the

firm and employee have prior (posterior) beliefs about the star's value creation potential. Throughout the employment lifecycle, both the firm and star learn about the star's "true" value creation potential, and update their posterior beliefs accordingly. To illustrate how such logic applies and informs the renegotiation process between the firm and the employee, consider the following example from the professional service industry.

\section{Framework and Stylized Illustration}

Figure 2 is a simplified framework depicting "the dance" involved in firms retaining stars. Across the figure, various stages of the employment relationship are listed, and down the rows, the evolution of the star's value creation potential, value appropriation, and decision rights are explained. The purpose of this framework is to provide a simple depiction of the "dance" between the employer (Party A) and the employee (Party B). For purposes of introducing ICT 
into the HR literature and extending RBT, this simplified model is sufficient. In time, this foundational framework can be enhanced by adding other parties (alternative employers) and employee characteristics (such as risk aversion), for example.

As seen in Figure 2, both the employee and the firm experience events during four phases of their relationship — initial hiring $(t 0)$, early development phase $(t 1)$, mid development phase $(t 2)$, and mastery $(t 3)$. By the time mastery has been achieved, the ability of the employee is known and there are few information asymmetries left. In fact, the information asymmetry advantage has shifted to the benefit of the employee as the organization may know how productive and visible the employee is, but it still does not know "how" the employee reached this position. In other words, the employee's ability is causally ambiguous. The events experienced during these phases help the firm and the employee learn about the likelihood of future events and shape their relationship through contract renegotiation (i.e., reduce informational asymmetries). These events are defined as experiential knowledge obtained from working and interacting together over time (Argote 1999; Argote, Beckman, and Epple 1990). Both parties obtain information, know-how, and feedback from these events (at $t 1, t 2, t 3$ ). Both employee and employer start at time 0 . For ease of example, one event datum is obtained per phase.

Each event enables both parties to learn and update their prior beliefs. For example, during the early development phase of the employment relationship, the individual may make investments to both their firm-specific human capital and their general human capital skills, which will influence their future ability to bargain and negotiate with the firm. Here we assume that at each point in time $t$, the value generated by the employee and the understanding of that value can change, and this change will determine how that value is captured in the next period, $t$ 
+ 1 (Bereby-Meyer and Roth 2006; Kalnins Swaminathan and Mitchell 2006). How value is captured between the parties can change in each period (Alvarez and Parker 2009), which relaxes the assumption of stable bargaining positions of the employee and employer that is implicit to much received HR and strategy research (Coff 2010) and lays the foundation for a theory to explain and predict employment dynamics and value-maximizing strategies for employees and their employers.

New Hire (t0). At the outset, the employee possesses only general human capital from, say, their MBA program and past work experience. In accordance with RBT, because the individual's human capital is general and somewhat abundant in the market, the employee will give up certain rights to their pay and decision making authority in order to gain more firmspecific and general human capital. After minor negotiations, the employee and firm will settle on a salary that will be based on limited information (on both sides) about the value of the individual's general human capital.

This situation is illustrated in Figure 2, in which a newly hired associate to a consulting firm may receive an average wage of $\$ 40$ per hour at $t 0$. Having just graduated with an MBA, $20 \%$ of the value created by this consultant may be from general human capital, while the other $80 \%$ is embedded within and specific to the firm (e.g., rooted in the processes, templates, and reputation of the firm). Since the human capital possessed by the associate is general, the firm uses these skills to plug into their firm-specific assets, which are creating most of the value. In a manufacturing setting, this would be akin to a machinist using a special piece of equipment to create value for the firm. Much of the value comes from the machine itself, not the machinist. Likewise, because it is the consulting firm's specific assets and not the consultant's general human capital that is creating most of the value, the firm will leverage this employee and 
possibly bill the client at $\$ 200$ per hour (U.S.). As a result, the individual is capturing $20 \%$ of the value created for the firm with their $\$ 40$ per hour wage. This $20 \%$ is consistent with the general human capital (e.g., general understanding of finance, ability to solve problems) possessed by the employee. The remaining $80 \%$ is rooted in the specific knowledge embedded inside the firm, and is accordingly captured by the firm (because the firm controls much of how the employee is to work and how the employee is rewarded).

The following equation assumes a majority of control (80\%) by the firm (A) and some residual control (20\%) by the employee (B). Here, $\Theta$ represents the overall amount of value captured in each time period.

$$
\theta\left(t_{0}\right)=\left(.8\left(\theta A\left(t_{0}\right)\right)+.2\left(\theta B\left(t_{0}\right)\right)\right.
$$

Based on the arguments above, employees with general human capital that is commonly found in the external market will generate little unique value and have little bargaining power.

Early Development (t1). During the early development phase $(t 1)$ of employment, employees spend much of their time developing firm-specific human capital regarding how work is done, where key resources are found, and who knows what in the firm. In this and other phases, both parties are assumed to learn (observe new data) and update their prior beliefs about one another's value creation potential and how they can maximize the value they capture from each other. For example, early on a new consultant will work to develop knowledge about how work gets done from both an informal network and formal process orientation, how resources are accessed and what political structures exist. This is also when skills are developed to adapt to 
coworker styles and trusting relationships are formed. Such firm-specific knowledge is valuable in understanding how the firm makes a unique contribution to their clients. During this time the employee is increasing the value they can create for the firm through firm-specific investments. At the same time, these firm-specific investments will also generate general human capital—the employee has co-developed human capital. Early on, however, such skills may not be as salient or developed as the firm-specific skills.

The employee's value-creation potential increases during this time, but their ability to capture an increased percentage of that value has not. As indicated in Figure 2, while the firm may be able to increase the billing rate (from $\$ 200$ to $\$ 300$ ) from the perspective of clients working with that consultant, the consultant will be able to capture a similar percent of value as before. The firm will now likely be able to pay the consultant at $\$ 60$ per hour, increasing the employee's value capture by $\$ 20$ and the firm's value capture by $\$ 80$ (from $\$ 160$ to $\$ 240$ ). This is because the employee's general human capital has grown only slightly since entering the firm and it is not enough to send signals to the market. In other words, because the majority of the value created was an increase due to firm-specific human capital (\$80 worth), the percentage of value created from general human capital has stayed the same at $20 \%$. This means that the firm can now capture the additional $\$ 80$ of $\$ 100$ of value created by the employee, increasing their returns to $\$ 240$. Such management practices are typical in professional service firms, where the largest gains in associates' value creation potential come after they have gotten to know the inner workings of the firm but before they have become recognized as stars (Maister 1997).

Because the employee's general human capital has increased only slightly in proportion to the firm-specific human capital, the bargaining power of the employee has not increased much. As a result, the firm will not be willing to offer decision rights beyond those necessary to 
secure good will or commitment. Hence, the value appropriation ratio remains the same, with the firm (A) possessing the residual rights (80\%) and the employee (B) the same as well (20\%). The difference now is that the overall value to be captured $(\Theta)$ has increased from $\$ 200$ to $\$ 300$. Thus, the employee captures $\$ 60$ and the firm now captures $\$ 240$.

$$
\theta\left(t_{1}\right)=\left(.8\left(\theta A\left(t_{1}\right)\right)+.2\left(\theta B\left(t_{1}\right)\right)\right.
$$

Based on the arguments above, employees will create unique value for the organization but have little bargaining power to capture the value they create.

Mid-Development (t2). During the mid-development phase ( $\mathrm{t} 2)$, with the star's growing expertise regarding how to use firm resources to exploit market opportunities, their co-developed human capital and its value begins to manifest. For example, as the consultant stays longer with the firm $(t+2)$, they may develop strong relationships with clients that yield important insights generalizable to the industry or market. Furthermore, the skills developed to work with specific individuals (e.g., managing a demanding client who attempts to change the scope of contracted work) or contexts (e.g., navigating ambiguity in a turbulent market) may generalize across multiple settings. Some of these skills may be tacit and not even entirely understood by the employee (Feldman and Ng 2007, Foss 2008). As the consultant's reputation grows, such knowledge generation abilities may begin to be seen within the industry and consulting labor market as valuable, despite their causal ambiguity and path dependence. In fact, research shows that as people reach this high visibility phase they are at much higher risk of being poached by other firms (Lee et al. 2008), as the labor market has swifter mechanisms for recognizing talent 
than the current employer. With this visibility and portability, the firm risks losing the consultant, unless they renegotiate the employment relationship and surrender some decision rights to the employee (Finnegan 2009). This logic is behind professional service firms often providing a larger stake in the direction and management of the firm and in how value is captured in the firm (Maister 1997).

With their co-developed human capital, the star's reliance on firm-specific resources to create value lessens and the potential value they can create for clients and the firm increases. Thus, as indicated in Figure 2, the shift in value creation away from firm-specific resources is reflected in the star appropriating as much as $40 \%$ of the value, and the firm $60 \%$. The star's greater value-creation potential is reflected in a higher billing rate, which has increased from say, $\$ 300$ to $\$ 600$. While the employee is now capturing $40 \%$ of the created value $(\$ 240)$, the firm is appropriating more value than in the prior stage ( $\$ 360$ vs. $\$ 240)$. The firm is better off capturing a smaller percentage of the value the employee creates and retaining them then letting the employee turnover.

Given their growing visibility in the market, the employee would likely begin to have outside offers from other firms, which provide the star and firm with information on the market value of the star's human capital. It is likely that the firm will not want to give up this person, thus they will renegotiate the employee's salary and decision making authority. A common concern with these high performing employees is that they may capture most of their expected value from a firm, and therefore they do not enhance firm performance (Ravid, 1999). While it is possible for an employee to capture more value than they create, most of the time the residual value captured by the firm for these employees is still higher than for non-star employees. As long as the value captured by the firm is greater than the prior time period and employees 
without the co-developed human capital, then the firm has a positive incentive to renegotiate and retain the employee. Hence, as listed in Figure 2, employee (B) now possesses a larger percent of residual rights $(40 \%)$ and the firm (A) less $(60 \%)$, while the entire value to be captured is $\$ 600$.

$$
\theta\left(t_{2}\right)=\left(.6\left(\theta A\left(t_{2}\right)\right)+.4\left(\theta B\left(t_{2}\right)\right)\right.
$$

Based on the arguments above, employees who have co-developed human capital will possess bargaining power that will allow them to capture more of the value they create.

Mastery (t3). During the mastery phase of employment ( $t 3)$, a knowledge worker will begin to leverage their co-developed generalizable and firm-specific skills, the combination of which are causally ambiguous and held by the employee (both within the firm and external to the firm). At this point, the individual may be seen as an industry expert and has developed a reputation both for themselves and the firm. Their long-standing relationships with clients and industry or market expertise may begin to yield important insights that generalize beyond the industry. Given their contributions and the use of up-or-out promotion systems in consulting (Maister, 1997), the star is likely to have become a partner during this time period, which sends competitors an important signal: the original employer believes the individual's past contributions and future potential contributions warrant ownership in the firm. Moreover, competitors face minimal risk in hiring the star, as it was the star's original employer who took the risk and bore the cost of developing the star. At this mastery stage, there are little to no information asymmetries left between the firm and consultant. In fact, the bargaining power 
advantage has shifted to the employee as the firm may know how productive the employee is, but it still does not know "how" the employee reached this position. In other words, the employee's productivity is causally ambiguous.

Now, the primary source of the value the employee creates shifts from firm-specific resources and human capital to the employee's co-developed human capital. Because the consultant can create greater value for clients, their billing rate increases (say from $\$ 600$ to \$1500). Given the labor market signal of the consultant being granted partnership, and likely industry news regarding the consultant's sales and/or thought leadership, the employee is likely to have outside offers, which give information about the employee's market value. However, it is likely that the firm will not want to give up this person, thus, as per Figure 2, the firm is likely to renegotiate the employee's salary and decision making authority. Continuing the employment relationship is in both parties best interests, as Groysberg et al. (2008) have shown that stars and potential alternative employers tend to underestimate the team production and institutional factors that contribute to the star's productivity (such as trusting relationships with co-workers and firm databases).

These dynamics are illustrated in Figure 2, which shows that the employee is now capturing $70 \%$ of the created value. In absolute terms, the firm is appropriating is more from the star than it does from non-star employees. So, if the employee is billing $\$ 1500$ per hour and captures $70 \%$ of that value, the employee captures $\$ 1050$ of that value while the firm captures $\$ 450$. The firm is better off capturing a smaller percentage of the value the employee creates, as their appropriation increases from $\$ 360$ to $\$ 450$. As long as the value captured by the firm increases from prior periods and is higher than that created by non-star employees, the firm has incentive to renegotiate the employment relationships and retain the employee. Indeed, even if 
the star wants to capture more value than they are producing on their own negotiations with the star could be warranted if the star's contributions to firm performance include direct effects (their own billings) and indirect effects, such as clients coming to the firm because of the star's employment and the star mentoring and developing other consultants. Thus, the employee (B) now possesses residual rights (70\% appropriation) and the firm (A) captures $30 \%$ of the increased value of $\$ 1500$. Thus:

$$
\theta\left(t_{3}\right)=\left(.3\left(\theta A\left(t_{3}\right)\right)+.7\left(\theta B\left(t_{3}\right)\right)\right.
$$

Based on the arguments above, employees who have co-developed human capital will possess bargaining power that allows them to capture most of the value they create.

In sum, when the consultant is first hired, the company possesses the residual rights of control. That is, while the firm does not possess the employee's human capital, the firm controls decision rights about how the value created from the employee's human capital is captured. Because firm-specific resources (e.g., firm processes, templates, client relationships) underlie the vast majority of value the consultant creates, the consultant does not have the bargaining power to gain value-appropriation decision rights. In contrast, as the consultant creates co-developed human capital and it is this co-developed human capital that yields the value the employee creates, it is in the firm's best interest to begin to surrender decision rights regarding how the business is run and value is captured. As a result, the consultant begins to capture more of the value they create and will be motivated to remain with the firm. As the star begins to be the party who has the most to gain from the employment relationship, rights of control shift from the 
firm to the employee. Simply put, the dynamic value appropriation process aligns the star's and firm's interests, creating a "win-win"—-the better the star performs the better the firm performs.

\section{Implications}

The framework provides a dynamic approach that incorporates issues of human capital, value capture, and how to manage star employees. This framework draws upon RBT, TCE and ICT and helps employers understand how to negotiate with employees to retain them. The illustration pushes HR and strategy scholars to think beyond human capital management as a cost or efficiency issue, and more as a dance to manage people (Boudreau and Ramstad 2004). This dance requires that we move beyond typical discussions of practices and policies to retain top talent, and shift to thinking about management as a continual negotiation process between the organization and its star employees and the conditions in which retention optimizes organizational performance. By doing so, we show how as some employees develop causally ambiguous, path dependent, and marketable general human capital, firms need to gradually offer more residual rights of control to the employees.

Offering decision rights is not a one-time act done when employees are hired or even as they reach past a certain threshold in the value of their human capital (e.g., achieving stardom). Rather, the shift in decision rights is best accomplished gradually as employees develop more codeveloped human capital, which is simultaneously valuable to the firm and visible on the labor market. As firms slowly surrender decision rights to employees as they develop into stars, both the organization and the employee will benefit.

This concept of achieving this balance is deceivingly simple yet has substantial implications for employees—and organizations employing knowledge workers with causally 
ambiguous and path dependent general human capital. Specifically, focus on a balanced solution essentially insulates organizations from losing employees who are demanding/expecting balanced relationships - and the framework developed in this paper can be used to inform retention policies for highly valuable and mobile employees.

Indeed, the framework provides a guideline for decisions about compensation actions and decision right allocations - in effect, the framework provides guidance about the conditions in which firms should "dance" with highly valuable, but mobile employees and when it is in the best interest of the firm to terminate the dance. Another benefit of the framework and illustration is that application of it essentially insulates the organization from harmful poaching. That is, although poaching is generally viewed as a negative (i.e., to lose an employee), the framework indicates in what conditions firm value is maximized by letting the employee go-and in effect letting the poaching firm overpay for the employee. In overpaying for the employee, the poaching firm endures a "winner's curse" (cf. Kagel and Levin 1986) as their bid exceeds the value the employee is likely to produce. In such situations, the only party extracting economic value is the employee themselves. Evidence of such outcomes is provided by Groysberg et al. (2008).

Managers are quick to point out that retaining knowledge workers, such as consultants, lawyers, bankers, programmers, and scientists is one of the primary difficulties they face. As stated by Greenwood et al. (2005: p. 663):

The professional workforce ... constitutes the critical asset of the professional service firm because it embodies, operates, and translates the knowledge inherent in the firm's output, and, it is the basis of the firm's relationships with clients who often follow professionals if they change firms. 
By focusing on how the residual rights of control in a firm can be negotiated over time we begin to understand how firms might retain key stars without losing the value they create for the firm. In fact, McGee (2003) pointed out that the fatal flaw in talking about value creation by employees is in adopting the perspective of the firm as the single beneficiary. Most research questions start by asking how the firm can capture full value from the employee. While this is important, another relevant question that must be asked is how can the highly productive star capture full value from the firm?

Of course, this framework does not apply to all situations and it will require significant modification as it is applied to star employees in different industries and across different organizations. For example, a large percentage of star workers are being contracted outside the firm (Bidwell, 2017; Bidwell \& Briscoe, 2009; Cappelli, 2008). Hence, many stars may no longer be internally hired inside the organization. Moreover, high status organizations usually do not need to pay early-stage stars as much as their less competitive peer organizations. As these employees become true stars, however, such high status organizations find that they need to raise the stars's wages more rapidly than other organizations whose employees make the same firmspecific human capital investments (Bidwell, Won, Barbulescu \& Mollick, 2015).

Despite these boundary conditions, we submit that a factor in improving firm performance through HR is to improve the negotiation process between key employees and managers of the organization. Taking a look at today's knowledge-based economy, it is apparent that this is a complex issue. No longer is it only the responsibility of HR to retain and motivate stars, but it is the responsibility of all managers within an organization. By training managers to more effectively deal with this renegotiation dance of knowing when and how to allocate decision rights to stars, a firm will be able to continually create and capture the maximum 
possible value from its employees. Applying the framework to managing stars will allow the organization to improve firm performance and maintain an advantage over other firms.

\section{Conclusion}

In this paper, we drew upon ICT to better understand the negotiation of value as star employees create value for the organization and demand some of this for themselves. We specifically examined how firm-specific investments can lead to general human capital that is highly sought after by competitors. Such a framework shows how the negotiation process involved in appropriating value from employees during their road to stardom is like a dance requiring give and take as the dance progresses. We demonstrated that the implicit assumption held by human resource and strategy theories that static positions of bargaining power between organizations and their employees does not hold across conditions. Rather, in conditions involving stars in human-capital intensive industries, in order for both employer and employee to optimize their relative outcomes, both parties must engage in a dance as employees simultaneously develop general and firm-specific human capital.

This unique extension of human capital theory regarding stars and employment, suggests future research that focuses more on dynamic models. Specifically, the framework points to dynamic approaches to managing stars that consider initial contracting of employment at time of hire and also re-contracting to retain the star in a way that optimizes firm value - and potentially star earnings as well. In addition, it is clarified that in order to optimize economic outcomes for the firm - and the employee - the firm must, over time, relinquish compensation decision rights and residual rights of control. In sum, the framework and stylized illustration provide a foundation for theory and practice regarding the strategic management of star human capital. 


\section{References}

Aguinis, H., \& O'Boyle Jr, E. 2014. Star performers in twenty-first century organizations. Personnel Psychology, 67(2), 313-350.

Aguinis, H., O'Boyle Jr, E., Gonzalez-Mulé, E., \& Joo, H. (2016). Cumulative advantage: Conductors and insulators of heavy-tailed productivity distributions and productivity stars. Personnel Psychology, 69(1), 3-66.

Alchian, A. A., H. Demsetz. 1972. Production, information costs, and economic organization. American Econom. Rev. 62(5) 777-795.

Alvarez, S. A., J. Barney. 2005. How entrepreneurs organize firms under conditions of uncertainty. J. Manag. 31(5) 776-793.

Alvarez, S. A., S. C. Parker. 2009. Emerging firms and the allocation of control rights: A Bayesian approach. Acad. of Manag. Rev. 34(2) 209-227.

Argote, L. 1999. Organizational Learning: Creating, Retaining, and Transferring Knowledge. Boston: Kluwer Academic Publishers.

Argote, L., S. L. Beckman, D. Epple. 1990. The persistence and transfer of learning in industrial settings. Manag. Sci. 36(2) 140-154.

Barney, J. B. 1991. Firm resources and sustained competitive advantage. J. Manag. 17 99-120.

Barney, J. B., M. H. Hansen. 1994. Trustworthiness as a source of competitive advantage. Strat. Manag. J. 15(8) 175-190.

Barney, J. B., P. M. Wright. 1998. On becoming a strategic partner: The role of human resources in gaining competitive advantage. Human Resource Manag. 37 31-46.

Baron, J. N., M. T. Hannan, \& D. M. Burton. 1999. Building the iron cage: Determinants of managerial intensity in the early years of organizations. American Sociological Rev. 64(4) 527-547.

Batt, R. 2002. Managing customer services: Human resource practices, quit rates, and sales growth. The Acad. of Manag. J. 45(3) 587-597.

Becker, B. E., M. A. Huselid. 1992. The incentive effects of tournament compensation systems. Adm. Science Quarterly. 37(2) 336-350.

Becker, B. E., M. A. Huselid. 2006. Strategic human resources management: Where do we go from here? J. Manag. 32(6) 898-925.

Becker, B., B. Gerhart. 1996. The impact of human resource management on organizational performance: Progress and prospects. Acad. of Manag. J. 39(4) 779-801.

Becker, G. S. 1964. Human Capital: A Theoretical and Empirical Analysis, with Special Reference to Education. Chicago: The University of Chicago Press.

Bereby-Meyer, Y., A. E. Roth. 2006. The speed of learning in noisy games: Partial reinforcement and the sustainability of cooperation. American Econom. Rev. 96(4) 10291042.

Bidwell, M. J., \& Briscoe, F. 2009. Who contracts? Determinants of the decision to work as an independent contractor among information technology workers. Academy of Management Journal, 52(6), 1148-1168.

Bidwell, M., Won, S., Barbulescu, R., \& Mollick, E. 2015. I used to work at Goldman Sachs! How firms benefit from organizational status in the market for human capital. Strategic Management Journal, 36(8), 1164-1173. 
Bidwell, M. J. (2017). Managing Talent Flows Through Internal and External Labor Markets. In Collings, Mellahi \& Cascio (Eds). The Oxford Handbook of Talent Management. Oxford University Press: Oxford, UK.

Blair, M. M. Firm-specific human capital and theories of the firm. In M. Blair \& M. Roe (Eds.) Employees and Corporate Governance, Brookings Institute Press, Washington, DC.

Boudreau, J. W., C. J. Berger. 1985. Decision-theoretic utility analysis applied to employee separation and acquisitions. J. Appl. Psych. 70(3) 581-612.

Boudreau, J. W., P. M. Ramstad. 2004. Strategic I/O psychology and the role of utility analysis models. In W. Borman, R. Klimoski, and D. Ilgen (Eds). Handbook of Industrial and Organizational Psychology. American Psychological Association: Washington, D. C.

Boxall, P. 2013. Mutuality in the management of human resources: assessing the quality of alignment in employment relationships. Human Resource Management Journal, 23(1), 3-17.

Brymer, R.A. and Sirmon, D.G., 2018. Pre-Exit Bundling, Turnover of Professionals, and Firm Performance. Journal of Management Studies, 55(1), pp.146-173.

Call, M. L., Nyberg, A. J., \& Thatcher, S. 2015. Stargazing: An integrative conceptual review, theoretical reconciliation, and extension for star employee research. Journal of Applied Psychology, 100(3), 623.

Campbell, B. A., Ganco, M., Franco, A. M., \& Agarwal, R. 2012. Who leaves, where to, and why worry? Employee mobility, entrepreneurship and effects on source firm performance. Strategic Management Journal, 33(1), 65-87.

Campbell, B. A., R. Coff, D. Kryscynski. 2012. Rethinking sustained competitive advantage from human capital. Acad. Manag. Rev. 37(3), 376-395.

Cappelli, P. 2001. Assessing the decline of internal labor markets. In I. Berg and A. Kleberg (Eds.), Sourcebook of labor markets, 207-245.

Cappelli, P. 2008. Talent management for the twenty-first century. Harvard Bus. Rev. 86(3) 7481.

Carmichael, L. 1983. Firm-specific human capital and promotion ladders. The Bell Journal of Economics. 14(1) 251-258.

Cascio, W. F. 1994. Costing Human Resources: The Financial Impact of Behavior in Organizations. San Francisco: Jossey Bass.

Chadwick, C. A. Dabu. 2009. Human resources, human resource management, and the competitive advantage of firms: Toward a more comprehensive model of causal linkages. Organization Science 20(1), 253-272.

Coff, R. W. 1997. Human assets and management dilemmas: Coping with hazards on the road to resource-based theory. Acad. Manag. Rev.22(2) 374-402.

Coff, R. W. 1999. When competitive advantage doesn't lead to performance: The resource-based view and stakeholder bargaining power. Org. Sci. 10(2) 119-133.

Coff, R. W. 2010. The coevolution of rent appropriation and capability development. Strat. Manag. J. 31(7) 711-733.

Coff, R. W. 2012. Strategic human capital paradoxes. Strategic Management Society Strategy Human Capital Newsletter 3(1) 9-10.

Coff, R. W. D. Krycynski. 2011. Drilling for micro-foundations of human capital-based competitive advantages. Journal of Management 37(5) 1429-1443.

Coff, R., \& Kryscynski, D. 2011. Invited editorial: Drilling for micro-foundations of human capital-based competitive advantages. Journal of Management, 37(5), 1429-1443. 
Collings, D. G. (2014). Toward mature talent management: Beyond shareholder value. Human Resource Development Quarterly, 25(3), 301-319.

Collings, D. G. (2017). Workforce Differentiation. In Collings, Mellahi \& Cascio (Eds). The Oxford Handbook of Talent Management. Oxford University Press: Oxford, UK.

Conner, K. R., C. K. Prahalad. 1996. A resource-based theory of the firm: Knowledge versus opportunism. Org. Sci. 7(5) 477-501.

Dalton, D. R., W. D. Todor., D. M. Krackhardt. 1982. Turnover overstated: The functional taxonomy. Acad. Manag. Rev. 7(1) 117-123.

Daniel, E., Di Domenico, M. and Nunan, D., 2018. Virtual Mobility and the Lonely Cloud: Theorizing the Mobility-Isolation Paradox for Self-Employed Knowledge-Workers in the Online Home-Based Business Context. Journal of Management Studies, 55(1), pp.174-203.

Delery, J.E., N. Gupta, J. D. Shaw. 1997. Human resource management and firm performance: A systems perspective. Proc. 1997 Southern Manag. Association Meeting. Atlanta, GA.

Feldman, D. C., T. W. Ng. 2007. Careers: Mobility, embeddedness, and success. J. Manag. 33(3) 350-377.

Felin, T., W. S. Hesterly. 2007. The knowledge-based view, nested heterogeneity, and new value creation: Philosophical considerations on the locus of knowledge. Acad. Manag. Rev. 32(1) 195-218.

Finnegan, R. P. 2009. Rethinking Retention in Good Times and Bad: Breakthrough Ideas for Keeping Your Best Workers. Davies-Black Publishing: NY.

Foss, K., N. J. Foss. 2005. Resources and transaction costs: How property rights economics furthers the resource-based view. Strat. Mgmt. J., 26 541-553.

Foss, N. J. 2008. Human Capital and Transaction Cost Economics. Copenhagen Business School Working Paper Series. Copenhagen Business School, Copenhagen, Denmark.

Foss, N. J., K. Foss. 2011. Understanding opportunity discovery and sustainable advantage: The role of transaction costs and property rights. Strat. Ent. J. 2 191-207.

Frank, R. H., P. J. Cook. 1995. The Winner-Take-All Society: How More and More Americans Compete for Even Fewer and Bigger Prizes, Encouraging Economic Waste, Income Inequality, and an Impoverished Cultural Life. Free Press: New York.

Gardner, T. M. 2005. Interfirm competition for human resources: Evidence from the software industry. Acad. of Manag. J. 48(2) 237-256.

Gowan, M. A., D. Lepak. 2007. Current and future value of human capital: Predictors of reemployment compensation following a job loss. J. of Emp. Counseling. 44(3) 135-144.

Greenwood, R., C. R. Hinings, J. Brown. 1990. "P2-Form” Strategic management: Corporate practices in professional partnerships. Acad. of Manag. J. 33(4) 725-755.

Greenwood, R., S. X. Li, R. Prakash, D. L. Deephouse. 2005. Reputation, diversification, and organizational explanations of performance in professional service firms. Org. Sci. 16 661673.

Grossman, S. J., O. D. Hart. 1986. The costs and benefits of ownership: A theory of vertical and lateral integration. J. Political Econ. 96(4) 691-719.

Groysberg, B., 2008. How star women build portable skills. Harvard Business Review, 86(2), p.74.

Groysberg, B., \& Lee, L. E. 2008. The effect of colleague quality on top performance: The case of security analysts. Journal of Organizational Behavior: The International Journal of Industrial, Occupational and Organizational Psychology and Behavior, 29(8), 1123-1144. 
Groysberg, B., A. Nanda, N. Nohria. 2004. The risky business of hiring stars. Harvard Bus. Rev. 82(5) 92-100.

Groysberg, B., L. Lee. 2010. Star power: Colleague quality and turnover. Industrial \& Corp. Change. 19(3) 741-765.

Groysberg, B., L. Lee., A. Nanda. 2008. Can they take it with them? The portability of star knowledge workers' performance. Manag. Sci. 54(7) 1213-1230.

Hannan, M. T., D. M. Burton, J. N. Baron. 1996. The road taken: Origins and evolution of employment systems in emerging companies. Industrial and Corporate Change. 5(2) 239275.

Hart, O. 1995. Firms, Contacts, and Financial Structure. Clarendon Press: Oxford.

Hart, O., J. Moore. 1988. Incomplete contracts and renegotiation. Econometrica. 56(4) 755-786.

Hart, R. A. (Ed.). 1988. Employment, unemployment and labor utilization. Boston: Unwin Hyman.

Hollenbeck, J. R., C. R. Williams. 1986. Goal Importance, self-focus, and the goal setting process. J. Applied Psych. 71(4) 606-611.

Huselid, M. A. 1995. The impact of human resource management practices on turnover, productivity, and corporate financial performance. Acad. Manag. J. 38(3) 635-672.

Jensen, M. C., \& Heckling, W. H. 1995. Specific and general knowledge, and organizational structure. Journal of Applied Corporate Finance, 8(2), 4-18.

Jovanovic, B. 1979. Firm-specific capital and turnover. J. of Political Economy. 87(6) 12461260.

Kagel, J. H., D. Levin. 1986. The winner's curse and public information in common value auctions. American Econ. Rev. 76(5) 894-920.

Kalnins, A., A. Swaminathan, W. Mitchell. 2006. Turnover events, vicarious information, and the reduced likelihood of outlet-level exit among small multiunit organizations. Org. Sci. 17 $118-131$.

Kang, S. S. S. Morris, S. A. Snell. 2007. Relational archetypes, organizational learning, and value creation: Extending the human resource architecture. Acad. of Manag. Rev. 32(1) 236256.

Kehoe, R. R., Lepak, D. P., \& Bentley, F. S. 2016. Let's call a star a star. Journal of Management.

Klein, B., R. G. Crawford., A. A. Alchian. 1978. Vertical integration, appropriable rents, and the competitive contracting process. J. Law \& Econom. 21(2) 297-314.

Kryscynski, D. and Ulrich, D., 2015. Making strategic human capital relevant: A time-sensitive opportunity. The Academy of Management Perspectives, 29(3), pp.357-369.

Lazear, E. P. 1986. "Raids and offer matching." Research in Labor Economics. R. G. Ehrenberg (Ed.)JAI: Greenwich, Conn.

Lazear, E. P. 2000. Performance pay and productivity. American Econom. Rev. 90(5) 1346-1361.

Lee, P. M. 1995. Bayesian statistics. London: Arnold.

Lee, T. H., B. Gerhart, I. Weller, C. O. Trevor. 2008. Understanding voluntary turnover: Pathspecific job satisfaction and the importance of unsolicited job offers. Acad. of Manag. $J$. 51(4) 651-671.

Lepak, D. P., K. G. Smith, M. S. Taylor. 2007. Value creation and value capture: A multi-level perspective. Acad. of Manag. Rev. 32(1) 180-194. 
Lepak, D. P., R. Takeuchi, S. A. Snell. 2003. Employment flexibility and firm performance: Examining the interaction effects of employment mode, environmental dynamism, and technological intensity. J. Manag. 29(5) 681-703.

Lepak, D. P., S. A. Snell. 1999. The human resource architecture: Toward a theory of human capital allocation and development. Acad. Manag. Rev. 24(1) 31-48.

MacDuffie, J. P. 1995. Human resource bundles and manufacturing performance: Organizational logic and flexible production system in the world auto industry. Industrial \& Labor Relations Rev. 48 197-221.

Maister, D. H. 1997. Managing the Professional Service Firm. Simon and Schuster: Boston.

Marx, M., D. Strumsky, L. Fleming. 2009. Mobility, skills, and the Michigan non-compete experiment. Manag. Sci. 55(6) 875-889.

McGee, M. K. 2003. Good as gone: Frustrated managers are ready to bolt if the economy heats up. Companies must work to retain them or get ready to replace them. Information Week 954 18-20.Milgrom, P., S. Oster. 1987. Job discrimination, market forces, and the invisibility hypothesis. Quarterly J. Econom. 102(3) 453-476.

Milgrom, P., \& Oster, S. 1987. Job discrimination, market forces, and the invisibility hypothesis. The Quarterly Journal of Economics, 102(3), 453-476.

Morris, S. S., Alvarez, S. A., Barney, J. B., \& Molloy, J. C. 2017. Firm-specific human capital investments as a signal of general value: Revisiting assumptions about human capital and how it is managed. Strategic Management Journal, 38(4), 912-919.

Morris, S. S., \& Oldroyd, J. B. (2017). Stars that Shimmer and Stars that Shine: How Information Overload Creates Significant Challenges for Star Employees. In Collings, Mellahi \& Cascio (Eds). The Oxford Handbook of Talent Management. Oxford University Press: Oxford, UK.

Nonaka, J. 1994. A dynamic theory of organizational knowledge creation. Org. Sci. 5(1) 14-37.

O'Boyle Jr, E., \& Aguinis, H. 2012. The best and the rest: Revisiting the norm of normality of individual performance. Personnel Psychology, 65(1), 79-119.

O’Boyle Jr, E. \& Kroska, S. (2017). Star Performers. In Collings, Mellahi \& Cascio (Eds). The Oxford Handbook of Talent Management. Oxford University Press: Oxford, UK.

Oldroyd, J. B., \& Morris, S. S. 2012. Catching falling stars: A human resource response to social capital's detrimental effect of information overload on star employees. Academy of Management Review, 37(3), 396-418.

Park, H.D., Howard, M.D. and Gomulya, D.M., 2018. The Impact of Knowledge Worker Mobility through an Acquisition on Breakthrough Knowledge. Journal of Management Studies, 55(1), pp.86-107.

Parsons, D. O. 1972. Specific human capital: An application to quit rates and layoff rates. J. of Political Econ. 80(6) 1120-1143.

Ployhart, R. E., \& Moliterno, T. P. 2011. Emergence of the human capital resource: A multilevel model. Academy of Management Review, 36(1), 127-150.

Ravid, S. A. 1999. Information blockbusters and stars - A study of the motion pictures industry. J. Business. October 363-392.

Rocha, V., Carneiro, A. and Varum, C., 2018. Leaving Employment to Entrepreneurship: The Value of Co-worker Mobility in Pushed and Pulled-Driven Start-ups. Journal of Management Studies, 55(1), pp.60-85.

Rousseau, D. M. 1995. Psychological Contracts in Organizations: Understanding Written and Unwritten Agreements. Sage: Thousand Oaks, CA. 
Somaya, D., I. O. Williamson, N. 2008. MIT Sln. Manag. Rev. 49(4) 29-34.

Sparrow, P. R., \& Makram, H. 2015. What is the value of talent management? Building valuedriven processes within a talent management architecture. Human Resource Management Review, 25(3), 249-263.

Spence, M. 1973. Job market signaling. The Quarterly J. of Econ. 87(3) 355-374.

Taylor, M. S., G. Audia, A. K. Gupta. 1996. The effect of lengthening job tenure on managers' organizational commitment and turnover. Org. Sci. 7(6) 632-648.

Trevor, C. O. 2001. Interactions among actual ease-of-movement determinants and job satisfaction in the prediction of voluntary turnover. Academy of Management Journal, 44(4), 621-638.

Trevor, C. O., A. J. Nyberg. 2008. Keeping your headcount when all about you are losing theirs: Downsizing, voluntary turnover rates, and the moderating role of HR practices. Acad. of Manag. J. 51(2) 259-276.

Trevor, C. O., B. Gerhart, J. W. Boudreau. 1997. Voluntary turnover and job performance: Curvilinearity and the moderating influences of salary growth and promotions. J. Applied Psych. 82(1) 44-61.

Trevor, C. O., J. P. Hausknecht, M. J. Howard. 2007. Why high and low performers leave and what they find elsewhere: Job performance effects on employment transitions. CAHRS Working Paper Series, WP07-11.

Tsui, A. S., J. L. Pearce, L. W. Porter, A. M. Tripoli. 1997. Alternative approaches of the employee-organization relationship: Does investment in employees pay off? Acad. of Manag. J. 40(5) 1089-1121.

Tzabbar, D., \& Kehoe, R. R. 2014. Can opportunity emerge from disarray? An examination of exploration and exploitation following star scientist turnover. Journal of Management, 40(2), 449-482.

Williamson, O. E. 1975. Markets and Hierarchies: Analysis and Antitrust Implications. Free Press: NY.

Williamson, O. E. 1975. Markets and hierarchies. New York, 2630.

Williamson, O. E. 1985. The Economic Institutions of Capitalism. Free Press: NY.

Wright, M., Tartari, V., Huang, K. G., Di Lorenzo, F., \& Bercovitz, J. 2018. Knowledge worker mobility in context: Pushing the boundaries of theory and methods. Journal of Management Studies, 55(1), 1-26.

Wright, P. M., G. C. McMahan. 1992. Theoretical perspectives for strategic human resource management. J. Manag. 18(2) 295-320.

Wright, P., G. McMahan, A. McWilliams. 1994. Human resources as a source of sustained competitive advantage: A resource-based view. International J. Human Resource Manag. 5 299-324. 


\section{Author Biographies}

Shad Morris (morris@ byu.edu) received his Ph.D. from Cornell University and is the Georgia White Fellow and Associate Professor of Management at the Marriott School of Business, Brigham Young University. He studies how organizations help (and hinder) employees in their efforts to create individual, organizational and societal value.

Sharon Alvarez salvarez@ katz.pitt.edu) is the Tom Olofson Chair in Entrepreneurship, Professor, Organizations and Entrepreneurship at the Joseph M. Katz School of Business, University of Pittsburgh. She received her Ph.D. from the University of Colorado. Her research focuses on the formation and exploitation of entrepreneurial opportunities and the implications of the process on firm formation, organizations, and institutions.

Jay Barney (jay.barney@ eccles.utah.edu) received his Ph.D. from Yale University and is a Presidential Professor of Strategic Management and the Pierre Lassonde Chair of Social Entrepreneurship at the University of Utah. He is editor-in-chief of the Academy of Management Review. His research focuses on costly to imitate capabilities and competitive advantage. 


\section{Figure 1 Theoretical Foundations}

\begin{tabular}{|c|c|c|c|}
\hline $\begin{array}{l}\text { Theoretical } \\
\text { Perspective }\end{array}$ & Core Human Capital Arguments & $\begin{array}{c}\text { Key } \\
\text { Constructs }\end{array}$ & Theoretical Assumptions \\
\hline $\begin{array}{l}\text { Resource - } \\
\text { based } \\
\text { theory }\end{array}$ & $\begin{array}{l}\text { Firm-specific (inimitable and rare) human } \\
\text { capital can underlie gains of superior firm } \\
\text { performance (Wright, Dunford and Snell, } \\
\text { 1999; Dierickx and Cool, 1991) }\end{array}$ & $\begin{array}{l}\text { Firm-specific } \\
\text { human capital; } \\
\text { competitive } \\
\text { advantage }\end{array}$ & $\begin{array}{l}\text { Stars are immobile due to } \\
\text { firm-specific investments; } \\
\text { general and firm-specific } \\
\text { human capital are separate; } \\
\text { firms control decision rights }\end{array}$ \\
\hline $\begin{array}{l}\text { Transaction } \\
\text { cost } \\
\text { economics }\end{array}$ & $\begin{array}{l}\text { Firms internalize employees with } \\
\text { firm-specific human capital, allowing the } \\
\text { firm to appropriate the value employees } \\
\text { with this human capital create (Lepak and } \\
\text { Snell, 1999; Williamson, 1981; 1985) }\end{array}$ & $\begin{array}{l}\text { Human asset } \\
\text { specificity; } \\
\text { internalization }\end{array}$ & $\begin{array}{l}\text { Stars are immobile due to } \\
\text { firm-specific investments; } \\
\text { general and firm-specific } \\
\text { human capital are } \\
\text { separate; firms control } \\
\text { decision rights }\end{array}$ \\
\hline $\begin{array}{l}\text { Incomplete } \\
\text { contract } \\
\text { theory }\end{array}$ & $\begin{array}{l}\text { As information asymmetries decrease } \\
\text { and shift, firms and employees need to } \\
\text { renegotiate who appropriates the value } \\
\text { (Alvarez and Parker, 2009; Grossman } \\
\text { and Hart, 1986; Hart and Moore, 1988) }\end{array}$ & $\begin{array}{l}\text { Rights of } \\
\text { control; } \\
\text { contract } \\
\text { renegotiation }\end{array}$ & $\begin{array}{l}\text { Parties' bargaining power } \\
\text { changes over time; } \\
\text { decision rights shift to the } \\
\text { party with the greatest } \\
\text { ability to create value }\end{array}$ \\
\hline
\end{tabular}

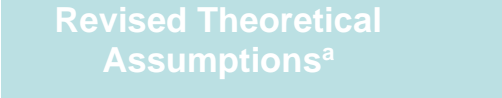

Firm-specific investments can enhance mobility.

\section{General and firm-specific} human capital are not necessarily separate; when developing firm-specific human capital, individuals can simultaneously develop (codevelop) general human capital.

Star and firm bargaining power are not stable, as implied by RBT and TCE; firms maximize value creation by shifting decision rights to stars over time.

a This column lists the theoretical assumptions underlying the Dynamic Value Appropriation framework (Figure 2). 


\section{Figure 2 A Dynamic Value Appropriation Framework}

$\mathrm{t} 0=$ =employee knowledge is unknown and general-firm possesses decision rights

Firm leads the dance t1=employee develops more firm-specific human capital; value unclear-firm offers up some decision rights

Employee becomes effective as a dance partner t3=employee has substantial codeveloped human capital and is highly visible in the industryfirm offers up residual rights of control

Star leads the dance

\section{Employee begins to lead}

the dance as a star negotiate value appropriation and control rights developed human capital that is causally ambiguous and path dependent and signaled to other potenital employers-firm must now

\begin{tabular}{|c|c|c|c|c|}
\hline \multirow[t]{2}{*}{ Characteristic } & \multicolumn{4}{|c|}{ Phases } \\
\hline & New Hire (to) & $\begin{array}{l}\text { Early Development } \\
\text { (t1) }\end{array}$ & Mid-Development (t2) & Mastery (t3) \\
\hline $\begin{array}{l}\text { Primary Source of } \\
\text { Value }\end{array}$ & $\begin{array}{l}\text { Firm-Specific } \\
\text { Resources }\end{array}$ & $\begin{array}{l}\text { Firm-Specific } \\
\text { Resources }\end{array}$ & $\begin{array}{l}\text { Firm-Specific and } \\
\text { General Resources }\end{array}$ & $\begin{array}{l}\text { General } \\
\text { Resources }\end{array}$ \\
\hline $\begin{array}{l}\text { Decision Rights } \\
\text { (Value } \\
\text { appropriation and } \\
\text { rights of control) }\end{array}$ & Firm has & Firm retains & $\begin{array}{l}\text { Firm and individual } \\
\text { share }\end{array}$ & $\begin{array}{l}\text { Shift to } \\
\text { individual }\end{array}$ \\
\hline Value & $\$ 200$ & $\$ 300$ & $\$ 600$ & $\$ 1500$ \\
\hline $\begin{array}{l}\text { Employee } \\
\text { Appropriation }\end{array}$ & $\$ 40(20 \%)$ & $\$ 60(20 \%)$ & $\$ 240(40 \%)$ & $\$ 1050(70 \%)$ \\
\hline $\begin{array}{l}\text { Firm } \\
\text { Appropriation }\end{array}$ & $\$ 160(80 \%)$ & $\$ 240(80 \%)$ & $\$ 360(60 \%)$ & $\$ 450(30 \%)$ \\
\hline
\end{tabular}

